\title{
PENGARUH PENDIDIKAN ETIKA TERHADAP PERSEPSI ETIS MAHASISWA AKUNTANSI \\ Padma Adriana
}

Jurusan Akuntansi Program Studi Akuntansi

Politeknik Negeri Malang

Email: padma.adriana.sari@gmail.com

\begin{abstract}
:
The main focus of this study is to understand the effect of business ethic course to student's ethical perception. This study used survey method in gathering the data, which used students from Politeknik Negeri Malang as the participants.Ethical perception was assessed by giving scenarios abaout unethical accountants, and students were asked to respond to questions about the scenarios. The analysis data method used independent sample t-test.The result of this study indicates that there were no significant difference between student's perceptions who have accomplished business ethics course and who have not accomplished the course yet.
\end{abstract}

Keywords: Ethics Education, Ethical Perception.

\begin{abstract}
Abstrak
Tujuan utama penelitian ini adalah untuk mengetahui pengaruh pemberian mata kuliah etika bisnis terhadap persepsi etis mahasiswa akuntansi. Populasi yang digunakan adalah mahasiswa Program Studi D-IV Jurusan Akuntansi Politeknik Negeri Malang. Penelitian ini menggunakan metode survey dalam pengumpulan datanya. Pengukuran persepsi etis dilakukan dengan memberikan skenario mengenai perilaku akuntan yang tidak etis, kemudian mahasiswa diminta untuk menilai etis tidaknya perilaku yang ada di dalam scenario tersebut. Metode analisis data yang digunakan yaitu uji beda independent sample t-test. Hasil penelitian menunjukkan bahwa mahasiswa yang sudah atau sedang mengambil mata kuliah etika bisnis dengan yang belum tidak memiliki perbedaan persepsi etis yang signifikan.
\end{abstract}

Kata kunci: Pendidikan Etika, Persepsi Mahasiswa Akuntansi. 


\section{PENDAHULUAN}

Profesi akuntan memegang peranan penting dalam dunia bisnis. Pemegang saham, kreditor, pemerintah, dan masyarakat bergantung kepada informasi yang disampaikan oleh akuntan dalam pengambilan keputusannya. Peran penting akuntan ini semakin menguat dengan adanya proses globalisasi ekonomi yang terjadi sekarang. Globalisasi ekonomimendorong tumbuhnya perusahaan multinasional yang beroperasi melewati batas-batas suatu negara. Makin banyaknya perusahaan-perusahaan multinasional maka semakin membutuhkan banyak akuntan dengan peran yang semakin besar. Hal ini memberikan tantangan dan peluang yang cukup besar bagi profesi akuntan di Indonesia untuk tumbuh dan berkembang (Ngumar, 1999).

Perkembangan profesi akuntan ini telah tercoreng dengan berbagai skandal di bidang akuntansi dan audit yang merusak citra profesi akuntan tersebut. Beberapa kasus besar yang terjadi di Amerika pada tahun 2009 sebagaimana dipaparkan dalam Securities Exchage Commision (2009) dalam Agoes, S. (2012) antara lainyaitu terjadinya manipulasi data pada transaksi sertifikat deposito milik nasabah sebuah bank besar yaituMillenium Bank. Kasus lain pada tahun yang sama dilakukan olehakuntan perusahaan International Realty Holdings, Inc. dengan menggelapkan dana milik investor.

Beberapa kasus yang terjadi di Indonesia pada tahun 2009 dilakukan oleh Akuntan Publik ZAF yang melanggar standar auditing dalam pelaksanaan audit atas laporan keuangan PT LILS tahun buku 2007 (Biro Hubungan Masyarakat Departemen Keuangan 2009 dalam Agoes, S., 2017). Kasus lain yang terjadi di Indonesia sebagaimana disampaikan di harian bisnis tempo (2017) yaitu di tahun 2017 KAP Purwantoro, Suherman dan Surja, yang merupakanKAP mitra Ernst \& Young (EY) di Indonesia, melakukan audit di sebuah perusahaan telekomunikasi dan memberikan hasil yang tidak sesuai dengan kondisi sebenarnya. Hasil audit menyatakan bahwa laporan keuangan perusahaan tersebut wajar tanpa pengecualian, padahal terdapat data yang tidak akurat pada persewaan ribuan tower perusahaan tersebut. Kasus lain di tahun 2017 dilakukan oleh kantor akuntan publik Deloitte \& Touche LLP yaitu membuat laporan audit palsu, sehingga harus membayar sejumlah denda yang cukup besar sebagai hukumannya.

Terus bermunculannya kasus etika yang melibatkan akuntan menandakan sangat kurangnya penerapan etika oleh akuntan. Padahal etika perlu selalu ditegakkan oleh akuntan untuk menjaga citra profesinya serta untuk menjaga kepercayaan masyarakat terhadap profesi 
akuntan. Oleh karena itu, perlu untuk terus melakukan penelitian tentang cara untuk menerapkan etika secara efektif sehingga pelanggaran etika dapat diminimalisir.

Mahasiswa akuntansi sebagai calon akuntan memegang peranan penting dalam pekerjaan yang akan dilakukannya. Sehingga perlu untuk membekali calon akuntan ini dengan ilmu pengetahuan dan etika, agar dapat melaksanakan pekerjaannya dengan penuh amanah.Suhartati, Nuraeni, dan Sixpria (2015) melakukan penelitian untuk mengeksplorasi aspek soft skill yang dibutuhkan oleh pengguna lulusan program studi akuntansi. Hasil penelitian tersebut menemukan bahwa lulusan program studi akuntansi perlu memilikietikaserta integritas dalam bekerja.Etika merupakan salah satu softskill penting yang dituntut oleh perusahaan yang harus dimiliki oleh karyawannya terutama di bidang akuntansi.

Menurut Duska (1991) sebagaimana dikutip Wati dan Sudibyo (2016) seseorang yang memiliki perilaku etisberarti telah mengetahui hal baik, menyukai hal baik, dan melakukan hal baik. Seseorang yang telah mendapat pendidikan etika diasumsikan telah mengetahui hal baik, sehingga memiliki perilaku yang lebih etis dibandingkan orang yang belum mendapatkan pendidikan etika. Penelitian lain mengenai etika dilakukan oleh Maryani dan Ludigdo (2001) yaitu mengenai faktor-faktor yang mempengaruhi sikap dan perilaku etis akuntan. Hasil penelitian tersebut menyatakan bahwa salah satu faktor yang mempengaruhi sikap dan perilaku etis akuntan adalah pendidikan. Berdasarkan penelitian di atas maka dapat disimpulkan bahwa pendidikan etika memegang peranan penting dalam merubah perilaku seseorang.

Salah satu bentuk upaya untuk membekali calon akuntan dengan etika dilakukan olehInternational Federation of Accountants (IFAC) denganmengeluarkan standar pendidikan internasional (International Education Standards/IES)untuk calon akuntan. Standar tersebut mengatur nilai-nilai yang harus diperoleh untuk memenuhi kualifikasi akuntan professional. Nilai tersebut antara lain yaitunilai profesional, etika dan sikap akuntan professional. Nilai-nilai ini perlu diberikan dengan tujuan agar calon akuntan dapat mengambil keputusan yang etis sesuai kepentingan masyarakat luas (http://iaiglobal.or.id).

Standar pendidikan internasional yang diterbitkan oleh International Federation of Accountants (IFAC), diterapkan oleh lembaga pendidikan dengan memberikan mata kuliah etika bisnis kepada mahasiswa. Pengajaran etika diberikan melalui pengajaran di kelas serta memberikan kuliah tamu kepada mahasiswa. Pengajaran ini diharapkan memberikan wawasan kepada mahasiswa mengenai bagaimana berperilaku etis serta mengambil keputusan-keputusan 
bisnis yang etis.

Wati dan Sudibyo (2016) telah melakukan penelitian mengenai pengaruh pendidikan etika bisnis terhadap persepsi etis mahasiswa akuntansi. Hasil penelitian mereka menunjukkan bahwa terdapat perbedaan persepsi etis antara mahasiswa yang sudah atau sedang mengambil mata kuliah etika bisnis dengan yang belum. Perbedaan persepsi etis ini juga ditemukan pada mahasiswa laki-laki dan perempuan.

Penelitian lain mengenai persepsi etis mahasiwa dilakukan oleh Wu (2008). Mahasiswa yang diteliti adalah mahasiswa Teknik dan Bisnis di Universitas Arkansas Tech.Wu meneliti mengenai perkembangan penilaian ethical reasoningdari mahasiwa baru sampai mahasiswa tingkat akhir. Hasil penelitiannya tidak menemukan perbedaan secara signifikan mengenai jawaban mahasiswa baik pada mahasiswa baru sampai dengan mahasiswa senior.

Adanya perbedaan hasil penelitian mengenai pengaruh pendidikan etika bisnis terhadap mahasiswa melatarbelakangi ditulisnya penelitian ini. Penelitian ini mengujiadanya pengaruh pendidikan etika terhadap persepsi etis mahasiswa akuntansi.Perbedaan dengan penelitian sebelumnya adalah pada penelitian ini mahasiswa yang dijadikan sampel adalah mahasiswa jurusan akuntansi di vokasi, yaitu Politeknik Negeri Malang.

Hasil penelitian ini diharapkandapat bermanfaat sebagai bahan masukan kepada Jurusan Akuntansi Politeknik Negeri Malang pada khususnya, atau instansi pendidikan lain mengenai pengajaran etika yang diberikan kepada peserta didiknya. Penyampaian materi etika bisnis dapat terus diperbarui sehingga semakin efektif diserap oleh mahasiswa, serta dapat diterapkan oleh mahasiswa dalam pekerjaannya nanti sebagai calon akuntan. Dengan semakin banyaknya penelitian mengenai pembentukan karakter etis mahasiswa, diharapkan lulusan akuntansi yang dihasilkan oleh instansi pendidikan di Indonesia semakin berkualitas dan beretika.

\section{TINJAUAN PUSTAKA}

\section{Etika dan Pengetahuan}

Rahardjo (2018) menyebutkan bahwa etika merupakan prinsip moral dan nilai yang diketahui sebagai sesuatu yang baik dan benar. Etika adalah sifat dasar yang harus dimiliki oleh seseorang atau sebuah organisasi sebagai pedoman berperilaku dalam kehidupan bermasyarakat.

Pengetahuan merupakan salah satu cara untuk memahami etika. Sebagaimana yang disampaikan oleh Rahardjo (2018), pengetahuan mengenai perilaku benar-salah atau baik-buruk 
diperoleh melalui pengalaman, pembelajaran dan pendidikan. Hal ini didukung oleh Nafis (2006) yang dikutip oleh Agoes (2014), yang menjelaskan bahwa etika perlu dilakukan antara manusia dengan dirinya sendiri terlebih dahulu, yaitu dengan sabar, syukur dan berilmu atau memiliki pengetahuan. Seseorang yang memiliki pengetahuan yang cukup mengenai etika maka akan dapat menerapkan nilai etika tersebut dalam kehidupannya sehari-hari.

\section{Etika Bisnis dan Etika Profesi}

Etika yang perlu diterapkan oleh akuntan adalah etika bisnis dan etika profesi. Etika bisnis mengatur tentang batasan-batasan perusahaan dalam mencapai tujuan mencari keuntungan, sedangkan etika profesi dikembangkan untuk meyakinkan kepada pemberi amanah (pemegang saham dan stakeholder lain) bahwa pekerjaan (audit) yag diberikan akan dilaksanakan dengan baik, demi kepentingan mereka (Rahardjo, 2018).

Ikatan Akuntan Indonesia telah merumuskan kode etik profesi akuntansi yang dapat digunakan sebagai pedoman bagi akuntan dalam menjalankan etika profesinya. Baidaie (2000) sebagaimana dikutip oleh Ludigdo (2007) menyatakan bahwa kode etik akuntan merupakan kaidah yang menjadi dasar terbentuknya kepercayaan masyarakat, karena dengan mematuhi kode etik akuntan diharapkan dapat menghasilkan kualitas kinerja yang paling baik bagi masyatakat.

Kode etik profesi akuntansi yang telah dirumuskan oleh Ikatan Akuntan Indonesia sebagaimana dipaparkan oleh Agoess dan Ardana (2014) terdiri atas delapan prinsip, yaitu:

1. Akuntan memiliki tanggung jawab profesi dengan selalu memberikaninformasi yang dapat dipercaya kepada masyarakat.

2. Mendahulukan kepentingan publik, yaitu selalu mementingkan kepentingan publik dibandingkan diri sendiri, atasan, maupun klien pemberi tugas.

3. Memiliki integritas dalam melaksanakan pekerjaanya.

4. Bekerja secara objektif.

5. Memiliki kompetensi ilmu pengetahuan yang sesuai dengan bidang akuntansi.

6. Menjaga kerahasiaan klien.

7. Memiliki perilaku professional.

8. Melaksanakan pekerjaan sesuai standar yang telah ditetapkan.

Berdasarkan kode etik profesi yang diuraikan di atas, maka dapat disimpulkan bahwa etika profesi akuntan telah diatur dengan seksama. Ditegakkannya kode etik profesi ini akan 
menyebabkan akuntanakan selalu mendapatkan kepercayaan dari pihak-pihak yang berkepentingan yaitu investor, kreditur, pemerintah dan masyarakat luas.

\section{Hipotesis Penelitian}

Penelitian yang dilakukan oleh Wu (2008) meneliti tentang perkembangan dan penilaian ethical reasoning untuk mahasiswa Teknik dan Bisnis di Universitas Arkansas Tech. Fokus utama penelitiannya adalah untuk mengetahui konsep bagaimana mengajar etika dan menilainya dalam lintas ilmu, apakah mahasiswa mengalami peningkatan dalam memberikan keputusan etis. Kuesioner yang digunakan adalah DIT 2 dan penilaian yang dikembangkan sendiri oleh peneliti. Untuk kedua instrumen tersebut, mahasiswa merespon pertanyaan pada scenario yang sudah disampaikan. Hasil penelitian ini tidak menemukan perbedaan secara signifikan mengenai jawaban mahasiswa baik pada mahasiswa baru sampai dengan mahasiswa senior.

Penelitian lain dilakukan oleh Sari(2012), yang memberikan hasil yang berbeda dari penelitian Wu. Pada penelitian Sari disebutkan bahwa muatan etika dalam pendidikan akuntansi mempunyai pengaruh signifikan terhadap persepsi etika siswa.Muatan etika dalam pendidikan disampaikan melakui pemberian tugas refleksi batin spiritual, diskusi di kelas mengenai masalah etika, serta penyelesaian kasus-kasus etika. Sari kemudian menjelaskan bahwa mahasiswa yang lebih memahami mengenai etika profesi akuntan akan semakin tidak setuju terhadap perilaku tidak etis akuntan dibandngkan dengan mahasiswa dengan pengetahuan dan pemahaman yang lebih sedikit.

Berdasarkan hasil-hasil penelitian sebelumnya, maka dapat disimpulkan bahwa semakin banyak pemahaman mengenai etika profesi akuntan maka seorang mahasiswa akan semakin tidak setuju dengan perilaku tidak etis akuntan dalam menghadapi dilema etis.Maka hipotesis (H1) dalam penelitian ini adalah terdapat perbedaan persepsi etis antara mahasiswa yang sudah atau sedang mengambil mata kuliah etika bisnis dan mahasiswa yang belum. 


\section{METODE PENELITIAN}

Populasi pada penelitian ini adalah mahasiswa program studi D-IV jurusan Akuntansi Manajemen Politeknik Negeri Malang dari angkatan 2014 sampai 2016. Penulis memberikan beberapa kriteria untuk pemilihan sampel penelitian dari populasi ini. Kriteria sampel yang digunakan dalam penelitian ini yaitu sebagai berikut:

1. Mahasiswa yang sudah atau sedang mengambil mata kuliah Etika Bisnis

2. mahasiswa yang belum mengambil mata kuliah Etika Bisnis.

Tabel 1 Karakteristik Demografi Responden

\begin{tabular}{|l|l|l|l|}
\hline \multicolumn{1}{|c|}{ Karakteristik } & \multicolumn{1}{|c|}{ Kategori } & \multicolumn{1}{c|}{ Jumlah } & \multicolumn{1}{c|}{ Persentase } \\
\hline Jenis Kelamin & Laki-Laki & 29 & $71 \%$ \\
& Perempuan & 72 & $42 \%$ \\
\hline Pendidikan Etika & Sudah atau Sedang & 42 & $58 \%$ \\
& Belum & 59 & \\
\hline
\end{tabular}

Studi kasus/kuesioner diberikan pada mahasiswa yang belum menempuh mata kuliah etika dan yang sudah atau sedang menempuh mata kuliah etika. Jawaban kedua kelompok mahasiswa ini dibandingkan untuk mengetahui apakah terjadi perbedaan mengenai persepsi etis kedua kelompok.

Sampel yang diperoleh yaitu 101 responden yang masih aktif dari Prodi Akuntansi Manajemen Jurusan Akuntansi Politeknik Negeri Malang dari angkatan 2014-2016. Waktu penelitian dilaksanakan pada Maret-Mei 2018. Dari populasi tersebut terdapat 29\% mahasiswa dan $71 \%$ mahasiswi. Jumlah persentase mahasiswa yang sudah atau sedang mengambil mata kuliah etika berjumlah $42 \%$, sedangkan yang belum berjumlah $58 \%$.

Jenis data yang digunakan dalam penelitian ini adalah data primer yang diambil secara langsung dari mahasiswa Program Studi D-IVJurusan Akuntansi Politeknik Negeri Malang. Data 
dikumpulkan menggunakan instrumen kuesioner yang didistribusikan secara online.

Instrumen Penelitian diadopsi dari kuesioner yang digunakan oleh Odar et al. (2017) yang kemudian disesuaikan dengan bahasa dan kondisi di Indonesia. Kuesioner penelitian ini mengukur persepsi mahasiswa mengenai etika bisnis dengan cara menceritakan 5 skenario yang dihadapi akuntan. Skenario berisikasus kepemilikan saham oleh auditor pada kliennya, manipulasi pajak, auditor yang diminta untuk sekaligus menjadi konsulan keuangan, sampai kasus nepotisme yang dilakukan akuntan bagian pembelian. Mahasiswa diminta untuk menilai seberapa etis keputusan yang diambil oleh akuntan pada kasus-kasus tersebut. Penilaian disediakan dengan skala Likert dimulai dari skala 1 (Sangat Tidak Etis), 2 (Tidak Etis), 3 (Etis), hingga skala 4 (Sangat Etis).

Instrumen yang digunakan pada penelitian ini selain mengadopsi dari penelitian terdahulu, juga melakukan penyesuaian pada beberapa kalimat yang digunakan. Oleh karena itu, dilakukan pengujian validitas serta pengujian reliabillitas sehingga dapat menghasilkan data yang akurat.Uji instrumen dilakukan menggunakan program SPSS versi 20.

Teknik yang digunakan dalam uji validitas yaitu teknik korelasi Product Moment dari Pearson dengan membandingkan nilai rhitung dengan rtabel. Suatu instrumen dikatakan valid apabila rhitung $>$ rtabel $(\mathrm{r} 100=0,195)$.Sedangkan teknik yang digunakan untuk mengetahui reliabilitas menggunakan uji internal consistency dengan melihat nilai Cronbach's Alpha. Suatu variabel dikatakan reliabel apabila nilai Cronbach's Alpha > 0,6 (Imam Ghozali, 2006: 46).

Data yang digunakan pada penelitian ini diuji dengan uji normalitas dan uji homogenitas yang merupakan prasyarat dalam melakukan analisis menggunakan uji beda t-test. Uji normalitasdilakukan untuk memastikan bahwa data telah terdistribusi normal. Uji statistik yang digunakan adalah teknik Kolmogorov- Smirnov. Data dikatakan normal apabila nilai taraf signifikansinya lebih dari 0,05.Uji kedua yang dilakukan yaitu uji homogenitas,yang dilakukan dengan tujuan untuk memastikan bahwa data bersifat homogen dalam suatu populasi yang memiliki varians yang sama. Apabila data yang digunakan homogen, maka dapat digunakan untuk proses analisis data pada tahap selanjutnya. Distribusi data dapat dikatakan homogen Jika nilai signifikansi $>0,05$, sedangkan jika nilai signifikansi $<0,05$ maka distribusi data adalah tidak homogen.

Uji hipotesis dilakukan dengan uji beda T-Test, yang dilakukan untuk mengetahui apabila terdapat perbedaan mengenai persepsi etis responden yang sudah atau sedang 
mendapatkan mata kuliah etika dengan yang belum., dengan rumus:

$t=\frac{\text { rerata sampel pertama - rerata sampel kedua }}{\text { standar error rerata kedua sampel }}$

(Imam Ghozali, 2011: 64)

Jika nilai $\mathrm{p}$ yang dihasilkan lebih besar dari 0,05 maka artinya adalah tidak terdapat perbedaan yang signifikan antara responden yang telah mendapatkan mata kuliah etika dan yang belum. Sebaliknya, jika nilai p kurang dari atau sama dengan 0,05 maka terdapat perbedaan signifikan antara responden yang telah mendapatkan mata kuliah etika dan yang belum.

\section{HASIL PENELITIAN}

Instrumen yang digunakan pada penelitian ini diuji validitas dan reliabilitasnya. Uji validitas menunjukkan bahwa untuk 4 item skenario pada kuesioner memiliki nilai korelasi (r) hitung lebih dari nilai korelasi (r) tabel, sedangkan 1 item dari 5 item skenario pada kuesioner dinyatakan tidak valid yaitu item nomor 5. Kriteria yang ditetapkan untuk uji reliabilitas yaitu memiliki nilai Corrected Item-Total Correlation lebih besar atau sama dengan $\mathrm{R}$ tabel, dengan jumlah $\mathrm{n}$ adalah 100, dan $\mathrm{R}$ tabel 0,195. Sedangkan hasil uji reliabilitas menunjukkan nilai Cronbach's Alpha di atas 0,6, yaitu 0,606. Hal ini menunjukkan bahwa instrumen yang digunakan reliable.

Berdasarkan uji normalitas yang dilakukan, diperoleh nilai Kolmogorov-Smirnov Z sebesar 0,265. Nilai ini lebih besar dari 0,05, yaitu syarat minimal nilai Kolmogorov-Smirnov Z untuk dapat dikatakan nilai residual berdistribusi normal. Maka dapat disimpulkan bahwa nilai residual pada data di penelitian ini berdistribusi normal. Sedangkan dari uji homogenitas yang dilakukan menunjukkan nilai sebesar 0.192. Nilai ini lebih besar dari 0,05, yaitu syarat minimal distribusi data dapat dikatakan homogen. Maka dapat disimpulkan bahwa distribusi data adalah homogen.

Tabel 2. Nilai dari Uji Independent Sample T-Test

\begin{tabular}{|l|l|r|r|r|r|}
\hline & Mata kuliah etika & $\mathrm{N}$ & \multicolumn{1}{|c|}{ Mean } & \multicolumn{1}{c|}{$\begin{array}{c}\text { Standar } \\
\text { Deviasi }\end{array}$} & \multicolumn{1}{|c|}{ Sig. } \\
\hline \multirow{2}{*}{ Persepsi etis } & belum mendapatkan & 56 & 8,48 & 2,027 & 0,192 \\
& Sudah atau sedang & 43 & 9,00 & 2,289 & \\
\hline
\end{tabular}


Setelah dipenuhi asumsi normalitas dan homogenitas, maka dapat dilakukan uji hipotesis. Berdasarkan hasil perhitungan terlihat bahwa nilai signifikansi lebih besar dari level of significant $(0,192>0,050)$, maka dapat disimpulkan bahwa antara responden yang telah menempuh mata kuliah etika dengan yang belum memiliki variance yang sama. Maka $\mathrm{H}_{1}$ yang menyatakan bahwa terdapat perbedaan persepsi etis antara yang telah atau sedang mengambil mata kuliah etika bisnis dengan yang belum,ditolak. Hal tersebut dibuktikan dengan rata-rata persepsi etis untuk responden yang sudah menempuh mata kuliah etika bisnis adalah 9, sedangkan untuk responden yang belum menempuh mata kuliah etika adalah8,48. Besarnya nilai F Levene test sebesar 1,724 dengan probabilitas 0,192.

Hasil penemuan dalam penelitian ini sejalan dengan penelitian yang dilakukan oleh $\mathrm{Wu}$ (2008). Wu (2008) meneliti perkembangan penilaian ethical reasoning untuk mahasiswa Teknik dan Bisnis di Universitas Arkansas Tech.Hasil penelitiannya tidak menemukan perbedaan secara signifikan mengenai jawaban mahasiswa baik pada mahasiswa baru sampai dengan mahasiswa senior.

Terdapat beberapa penelitian sebelumnya yang memiliki hasil bertentangan dengan penelitian ini. Antara lain adalah hasil penelitian yang dilakukan oleh Wati dan Sudibyo (2016) serta Suwardi et al. (2014), yang menemukan perbedaan persepsi etis antara mahasiswa yang telah atau sedang mendapatkan mata kuliah etika bisnis dengan yang belum. Penemuan ini juga bertentangan dengan hasil penelitianyang dilakukan oleh Sari(2012), yang menemukan bahwa muatan etika dalam pendidikan akuntansi mempunyai pengaruh signifikan terhadap persepsi etis siswa.

Pada penelitian Sari(2012) disampaikan bahwa pemberian etika kepada mahasiswa disampaikan dengan cara memberikan tugas Refleksi Batin Spiritual, pembahasan mengenai berita hangat yang berhubungan dengan etika, serta diskusi mengenai kasus-kasus etika yang terjadi di dunia ekonomi dan bisnis. Materi etika juga disampaikan dalam bentuk olah akal, olah rasa, olah batin untuk mengembangkan kecerdasan intelektual, emosional dan spiritual dengan memasukkan materi tersbut ke dalam kurikulum yang digunakan sehingga dapat meningkatkan kepekaan mahasiswa terhadap isu-isu etika.

Pada responden yang diteliti oleh penulis, muatan etika pada mata kuliah etika bisnis disampaikan pada proses belajar mengajar dengan cara membahas isu etika, melakukan diskusi, serta penyelesaian kasus etika. Namun belum menerapkan refleksi batin spiritual, sebagaimana 
disampaikan olehSari (2012) denganmengutip Triyuwono (2010), yang menyatakanbahwa aspek pembelajaran memerlukan pendekatan olah akal, olah rasa, dan olah batin.Proses pembelajaran dengan pendekatan ini bertujuan untuk mengembangkan kesadaran etis dan perilaku etis dengan cara memahami nilai-nilai etika tidak hanya dari literatur yang ada, namun juga dari pengalaman hidup diri sendiri maupun pengalaman hidup orang lain, serta melakukan penguatan secara emosi dan spiritualitas.

Penguatan spiritualitas sebagai proses pembelajaran didukung oleh Agoes dan Ardana (2014) yang menyampaikan bahwa ajaran agama dapat dijadikan panduan dalam pengembangan olah batin, serta menjadi sarana untuk melakukan pendekatan melalui proses nalar, pengamalan, dan pengalaman langsung melalui refleksi diri. Ajaran-ajaran baik yang disampaikan oleh agama ini dipelajari, direnungi, diresapi dan diamalkan dalam kehidupan sehari-hari. Proses penguatan spiritualitas ini menjadikan seseorang dapat melakukan proses transformasi diri untuk mencapai karakter ideal. Hal ini menjadi tahapan besar bagi seseorang untuk mengambil langkah dalam menerapkan nilai-nilai etika yang telah mereka pelajari dan pahami sebelumnya. Nilai-nilai etika yang dipelajari tidak hanya sebagai pengetahuan saja, namun dapat diintegrasikan dalam segala kegiatan yang dilakukannya serta keputusan yang diambil.

Agoes dan Ardana (2014) kemudian menyampaikan bahwa karakter seseorang berkaitan erat dengan kondisi pikirannya. Ketika berada dalam keadaan sadar, pikiran sangat aktif sehingga menyebabkan rasa cemas, khawatir, gelisah, dan sebagainya. Oleh karena itu, pikiran harus dilatih untuk memasuki gelombang alpha untuk membangun karakter positif seperti tenang, sabar, nyaman, ikhlas, bahagia, dan sejenisnya. Kunci untuk membangun karakter adalah melatih pikiran untuk memasuki gelombang alpha. Hal ini dilakukan dengan meditasi, dzikir, yoga, dan kegiatan lainnya yang melatih pikiran untuk tenang dan berkonsentrasi.

Metode alternatif untuk pemberian materi etika kepada mahasiswa di atas dapat terus dikembangkan agar semakin efektif memberikan pengaruh positif untuk membangun kesadaran etika. Namun, selain dari metode pemberian mata kuliah tersebut, nilai etika juga perlu diberikan pada mata kuliah lain yang ditempuh oleh mahasiswa selain dari mata kuliah etika. Penelitian yang dilakukan oleh Afiatin (2014)menyatakan bahwa pembelajaranpendidikan karakter dan etika profesi bukan tanggung jawab mata kuliah tertentu yang berdasar kurikulum yang memang bermuatan aspek etika, tetapi akan menjadi lebih bermakna jika semua komponen dalam pendidikan terlibat dalam pembentukan karakter mahasiswa. Berbagai strategi pembelajaran 
pendidikan karakter dan etika dapat diterapkan. Strategi pembelajaran yang terintegrasi di dalam mata kuliah maupun mata kuliah lain yang dipelajari oleh mahasiswa tersebut.

Sari(2012) menyampaikan bahwa aspek etika yang disertakan dalam mata kuliah etika bisnis dan profesi serta mata kuliah akuntansi lain akan memberikan kemampuan pada mahasiswa untuk memperkuat persepsi moral dan pertimbangan etis. Berdasarkan hal ini dapat disimpulkan bahwa dengan semakin senior mahasiswa dan mata kuliah yang dipelajari juga semakin banyak dan memasukkan unsur etika dalam pembelajarannya, maka mahasiswa tersebut diharapkan dapat mengambil keputusan yang semakin etis. 


\section{SIMPULAN DAN SARAN}

Berdasarkan hasil penelitian yang dilakukan, tidak terdapat perbedaan signifikan pada persepsi etis antara mahasiswa yang telah atau sedang menempuh mata kuliah etika dengan yang belum.Kesimpulan ini didukung dengan hasil uji independent t-test yang memberikan hasil perhitungan nilai signifikansi yang lebih besar dari level of significant $(0,192>0,050)$.

Penyebab tidak adanya perbedaan yang signifikan antara mahasiswa yang telah atau sedang menempuh mata kuliah etika dengan yang belumdapat disebabkan oleh beberapa hal. Hal pertama yang dapat menjadi penyebab tidak ditemukannya perbedaan persepsi etis pada dua kelompok mahasiswa yaitu pemberian materi mata kuliah etika yang belum memasukkan unsur olah rasa dan olah batin. Olah rasa dan olah batin dilakukan dengan pembelajaran melalui nilainilai yang diperoleh dari literatur, pengalaman hidup, serta pemahaman etika melalui penguatan emosi dan spiritualitas. Penguatan emosi dan spiritualitas ini menjadi tahapan besar bagi seseorang untuk mengambil langkah dalam menerapkan nilai-nilai etika yang telah mereka pelajari dan pahami sebelumnya. Akibatnya adalah nilai-nilai etika yang dipelajari tidak hanya sebagai pengetahuan saja, namun dapat diintegrasikan dalam tindak tanduknya terutama melakukan pekerjaan sebagai akuntan.

Faktor penyebab yang keduaadalah aspek etika belum diintegrasikanpada mata kuliah akuntansi lain selain etika bisnis. Integrasi nilai-nilai etika pada mata kuliah akuntansi dapatmelatih mahasiswa untuk meningkatkan persepsi moral serta pertimbangan etis mereka. Semakin sering mahasiswa memperoleh materi etis dalam pembelajarannya maka diharapkan materi etika tersebut semakin dapat diserap oleh mahasiswa sehingga dapat mempengaruhi pertimbangan etisnya.

Faktor berikutnya adalah pengambilan sampel mahasiswa yang berbeda yang diteliti yaitu dari mahasiswa semester 4,5, dan 6. Menurut Smith (2009) sebagaimana dikutip oleh Wati dan Sudibyo (2016) setiap mahasiswa memiliki persepsi moralserta sikap yang tidak sama, meskipun masing-masing dari mereka diberikan materi etika dengan jumlah yang sama. Oleh karena itu, akan lebih baik apabila mahasiswa yang sama yang belum menempuh mata kuliah etika bisnis diteliti lagi di semester berikutnya setelah menempuh mata kuliah etika bisnis, untuk melihat perubahan pengambilan keputusan etis yang diambil oleh mahasiswa tersebut.

Penelitian selanjutnya dapat menggunakan sampel mahasiswa yang sama untuk diteliti dalam beberapa tahun, sehingga dapat lebih seksama dalam mengukurperubahankeputusan etis 
yang diambil oleh mahasiswa tersebut sebelum mendapatkan mata kuliah etika dan setelah mendapatkan mata kuliah tersebut. Selain itu, dapat digunakan kuesioner berbeda seperti DIT 2 yang telah dikembangkan oleh peneliti sebelumnya dalam mengukur pengambilan keputusan etis. 


\section{DAFTAR PUSTAKA}

Afiatin, Y. (2014). Pendidikan Karakter Sebagai Upaya Pembekalan Etika Profesi bagi Mahasiswa melalui Pembelajaran di Perguruan Tinggi. Prosiding Simposium Nasional Akuntansi Vokasi ke-3, Padang, 12-14 Juni 2014. ISSN 2302-741X.

Agoes, S. (2012). Auditing (Edisi 4, Buku 1) . Jakarta: Salemba Empat.

Agoes, S. dan Ardana, I Cenik. (2014). Etika Bisnis dan Profesi, Tantangan Membangun Manusia Seutuhnya, Edisi Revisi. Jakarta: Salemba Empat.

Arfan Ikhsan Lubis. 2010. Akuntansi Keperilakuan Edisi.2. Jakarta: Salemba Empat

Frederich dan Lindawati (2004) Frederich O.L. dan Lindawati. 2004. Manajemen Laba dalam Persepsi Etis Akuntan di Pulau Jawa. Jurnal Widya Manajemen dan Akuntansi. Vol. 4 no.1, Okt : 1-26.

Ghozali, Imam. 2006. Aplikasi Analisis Multivariate dengan Program SPSS. Yogyakarta: Penerbit Universitas Diponegoro.

IAI. 2008. Standar Pendidikan Internasional IFAC. Diperoleh tanggal 5 mei 2018 di http://iaiglobal.or.id/v03/berita-kegiatan/detailarsip-8.

Ludigdo, Unti. 2007. Paradoks Etika Akuntan. Yogyakarta: Pustaka Pelajar.

Maryani, T. dan U. Ludigdo. 2001. Survei Atas Faktor-Faktor yang Mempengaruhi Sikap dan Perilaku Etis Akuntan.TEMA. Volume II Nomor 1. Maret. p. 49-62.

Ngumar, Sutjipto. 1999. Meningkatkan Peran Akuntan Indonesia di Era Globalisasi. Ekuitas Vol.3 No.1 Maret 1999 : 32-44

Odar, et al. 2017. Accountants Ethical Perceptions from Several Perspectives: Evidence from Slovenia. Economi Research-Ekonomska Estrazivanja. Vol.30 No.1, 1785-1803.

Rahardjo, Soemarso Slamet. 2017. Etika dalam Bisnis dan Profesi Akuntan dan Tata Kelola Perusahaan. Jakarta: Salemba Empat.

Sari, Lita P. 2012. Pengaruh Muatan Etika dalam pendidikan Akuntansi terhadap Persepsi Etika Mahasiswa. Jurnal Akuntansi Multiparadigma, Volume 3, Nomor 3, Desember 2012, Hlm 380-392

Suwardi et al. 2014.Student Perception On Business Ethics.Journal of Indonesian Economy and Business. Volume 29, Number 3, 2014, $251-258$ 
Suhartati, Nuraeni, dan Sixpria. 2015. Studi Kebutuhan Soft Skill dalam Upaya Penyusunan Model Pembelajaran Soft Skill yang Terintegrasi dengan Mata Kuliah Akuntansi. Account Jurnal Akuntansi, Keuangan dan Perbankan Vol 1 No 3 Juni 2015. ISSN 2338-9753

Triyuwono. 2010. Mata Ketiga: Se Laen, Sang Pembebas Sistem PendidikanTinggi Akuntansi.Jurnal Akuntansi Multiparadigma. Vol 1, No1, hal 1-23.

Tempo.co. 2017. Mitra Ernst \& Young Indonesia Didenda Rp. 13 Miliar di AS, diperoleh tanggal 1 Mei 2018 di https://bisnis.tempo.co/read/845604/mitra-ernst-young-indonesiadidenda-rp-13-miliar-di-as.

Wati, Mirna dan Sudibyo, Bambang. 2016. Pengaruh Pendidikan Etika Bisnis dan Religiusitas terhadap Persepsi Etis Mahasiswa Akuntansi. Jurnal Economia, Volume 12, Nomor 2, Oktober 2016.

Wu, Chih-Hao. 2008.Does Education Have an Impact on Student Ethical Reasoning? Developing an Assessment of Ethical Reasoning for Engineering and Business Students. Proceedings of the 2008 Midwest Section Conference of the American Society of Engineering Education. 